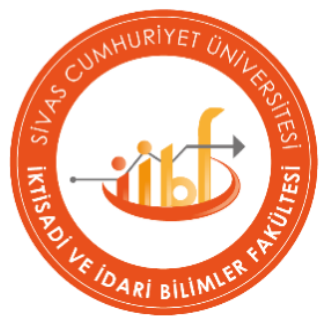

\title{
MODERATED MEDIATION EFFECT OF FEAR OF COVID-19 AND ORGANIZATIONAL TRUST ON THE RELATIONSHIP BETWEEN PERCEIVED ORGANIZATIONAL SUPPORT AND HELPING CO-WORKERS DURING THE PANDEMIC: A STUDY ON HEALTH PROFESSIONALS
}

\author{
Oğuz DEMIREL ${ }^{1}$ \\ Fuat YALMAN ${ }^{2}$
}

Article History:

Date submitted:

1 September 2021

Date accepted:

13 December 2021

\section{Abstract}

In this study, firstly, the mediating role of organizational trust in perceived organizational support and helping co-workers was examined. Then, the moderating role of COVID-19 fear on organizational trust and helping coworkers was tested. The study was performed on 401 health professionals working in public hospitals in Turkey. The data were collected through the questionnaire and were analyzed by structural equation modeling and hierarchical regression technique. According to the findings of the study, perceived organizational support has a positive and significant effect on helping co-workers. In addition, organizational trust has a full mediating effect on this relationship. Finally, the moderating role of COVID-19 fear on the relationship between organizational trust and helping co-workers has not been established.
Jel Codes:

M10, M12, M19

Keywords:

Perceived

Organizational

Support,

Organizational Trust, Helping Co-Workers, Fear of COVID-19

Suggested Citation: Demirel, O. \& Yalman, F. (2022). Moderated Mediation Effect of Fear of Covid-19 and Organizational Trust on the Relationship Between Perceived Organizational Support and Helping Co-Workers During the Pandemic: A Study on Health Professionals. Cumhuriyet University Journal of Economics and Administrative Sciences, 23(1), 79-93.

${ }^{1}$ Dr. Res. Asst., Düzce University, Faculty of Business Administration, Department of Management Information Systems, oguzdemirel@ duzce.edu.tr, ORCID ID: 0000-0003-1436-860X

${ }^{2}$ Asst. Prof. Dr., Düzce University, Faculty of Business Administration, Department of Health Management, fuatyalman@duzce.edu.tr, ORCID ID: 0000-0002-1041-1837 


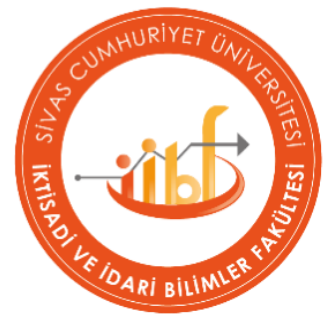

\section{SAĞLIK PROFESYONELLERINDE GÜVEN VE COVID-19 KORKUSUNUN ÖRGÜTSEL DESTEK VE ÇALIŞMA ARKADAŞLARINA YARDIM İLIŞSISISI ÜZERINDEKİ ETKİSI}

\section{Oğuz DEMIREL ${ }^{1}$ Fuat YALMAN ${ }^{2}$}

$\ddot{O} z$

Bu araştırmada ilk olarak, örgütsel güvenin algilanan örgütsel destek ile çalışma arkadaşlarına yardım ilişkisindeki aracılık rolü incelenmiştir. Ardından, COVID-19 korkusunun örgütsel güven ile çalışma arkadaşlarına yardım ilişkisi üzerindeki düzenleyici rol sınanmıştır. Çalışma, Türkiye'deki kamu hastanelerinde görev yapan 401 sağlık profesyoneli üzerinde gerçekleştirilmiştir. Anket yoluyla toplanan veriler yapısal eşitlik modellemesi ve hiyerarşik regresyon tekniği ile analiz edilmiştir. Araştırmanın bulgularına göre, algılanan örgütsel desteğin çalışma arkadaşlarına yardım üzerinde pozitif ve anlamlı bir etkisi bulunmaktadır. Ayrıca örgütsel güvenin bahse konu ilişki üzerinde tam aracılı etkisi mevcuttur. Son olarak, COVID-19 korkusunun örgütsel güven ile çalışma arkadaşlarına yardım ilişkisinde düzenleyici rolü tespit edilmemiştir.
Makale Geçmişi:

Iletilen Tarih:

1 Eylül 2021

Kabul Tarihi:

13 Aralık 2021

Jel Kodlart:

M10, M12, M19

Anahtar Kelimeler:

Algllanan Örgütsel

Destek, Örgütsel

Güven, Çalı̧̧ma

Arkadaşlarına Yardım,

COVID-19 Korkusu

Önerilen Alıntı: Demirel, O. \& Yalman, F. (2022). Sağlık Profesyonellerinde Güven ve Covid-19 Korkusunun Örgütsel Destek ve Çalışma Arkadaşlarına Yardım İlişkisi Üzerindeki Etkisi. Cumhuriyet Üniversitesi İktisadi ve İdari Bilimler Dergisi, 23(1), 79-93.

${ }^{1}$ Dr. Arş. Gör., Düzce Üniversitesi, İşletme Fakültesi, Yönetim Bilişim Sistemleri Bölümü, oguzdemirel@duzce.edu.tr, ORCID ID: 0000-0003-1436-860X

${ }^{2}$ Dr. Öğr. Üyesi, Düzce Üniversitesi, İşletme Fakültesi, Sağlık Yönetimi Bölümü, fuatyalman@duzce.edu.tr, ORCID ID: 0000-0002-1041-1837 
Oğuz DEMİREL \& Fuat YALMAN, 22 Cilt: 23, Sayl: 1, ss. 79-93.

\section{INTRODUCTION}

Today, it is accepted that the helping behavior of an organization's employees creates benefits for organizations (Anderson and Williams, 1996; Ng and Van Dyne, 2005). Helping behavior refers to the behavior that includes voluntarily helping to co-workers for solving and preventing problems (Podsakoff et al., 2000). It is described as a form of organizational citizenship behavior that involves interpersonal, cooperative actions (Massholder et al., 2011). The positive outcomes of helping behavior led organizational behavior researchers to focus on the possible antecedents to understand the underlying psychological and organizational mechanisms. For instance, studies revealed that leadership (Lim and Moon, 2020; Zhu and Akhtar, 2014), prosocial motivation (Choi and Moon, 2016) and family-to-work conflict (De Clercq et al., 2019) have strong associations with the helping behaviors.

Perceived organizational support has also been investigated as a predictor of helping behavior. However, helping co-workers has been examined heavily through the lens of citizenship behavior and thus, the associations between perceived organizational support and organizational citizenship behaviors of employees have been studied (e.g. Cheung, 2013; Moorman et al., 1998). Based on the arguments above and to improve our understanding, it is meaningful to focus on the helping behavior dimension of organizational citizenship and to highlight its relationship with individual and organizational factors.

The coronavirus disease called COVID-19 is a newly discovered type of infectious disease and its etiology is not fully known (World Health Organization, 2020a). Due to the spread of the virus to Europe and the U.S. in a short time, the World Health Organization has declared COVID19 as a pandemic (global epidemic) as of March 11, 2020. As the pandemic brings up many additional medical or social behavior changes, it has been emphasized that the obligation to comply with the rules requires a sustainable adaptation skill. Because of the difficulty in alignment, unmanageable levels of anxiety and fear are noted (Psychiatric Association of Turkey, 2020). In this context, it is important to examine the effects of fear of COVID-19 on the behavior of healthcare professionals, whose contact with the New Coronavirus is much higher than other employees since the beginning of the pandemic. In this study, we examined the associations among perceived organizational support, organizational trust, and helping behaviors of health professionals, and the moderation role of fear of COVID-19.

This study has two important contributions. First, it enhances helping behavior literature by investigating the effect of an extraordinary phenomenon, the COVID-19 pandemic. Second, the findings highlight the mediator role of organizational trust in the relationship between perceived organizational support and helping co-workers.

\section{LITERATURE REVIEW AND HYPOTHESIS DEVELOPMENT}

\subsection{Effects of Fear of COVID-19 on Behaviors}

The SARS-COV-2 virus, which was first seen in Wuhan, China in December 2019, defined as "New Coronavirus Disease/COVID-19" and caused a deadly disease, was declared as a global epidemic by the World Health Organization (WHO) (World Health Organization, 2020b). The coronavirus disease called COVID-19 is a newly discovered type of infectious disease and its etiology is not fully known (World Health Organization, 2020b). Due to the spread of the virus to Europe and the United States in a short time, the World Health Organization has declared COVID- 
MODERATED MEDIATION EFFECT OF FEAR OF COVID-19 AND ORGANIZATIONAL TRUST

ON THE RELATIONSHIP BETWEEN PERCEIVED ORGANIZATIONAL SUPPORT AND

HELPING CO-WORKERS DURING THE PANDEMIC: A STUDY ON HEALTH PROFESSIONALS

19 as a pandemic (global epidemic) as of March 11, 2020. Since the pandemic brings up many additional medical or social behavior changes, the obligation to comply with the rules requires a sustainable adaptation skill. Because of the difficulties of adaptation, anxiety, and fear cannot be managed in a short time (Psychiatric Association of Turkey, 2020).

Similarly, the nature of the COVID-19 pandemic has also been observed to commonly cause anxiety, fear and depression in society. In addition, the lack of an effective treatment method for the virus has further increased these feelings and created uncertainty about where the process will go (Ahorsu et al., 2020). At the same time, disease outbreaks such as the COVID-19 pandemic are seen as situations of concern. Even if the impact of this pandemic on global mental health has not been recorded and measured, it has been observed that individuals' levels of fear and anxiety increase especially during the emergence of the pandemic and the number of cases (Rajkumar, 2020). It is reported that confronting uncertain situations, especially when there is a potential risk of death, can increase people's levels of anxiety and fear, and this can lead both healthy and vulnerable individuals to engage in protective behavior (Shigemura et al., 2020).

In another study, it is emphasized that the fear of COVID-19 will have a great impact on the mental health (Torales et al., 2020). Therefore, the nature of the COVID-19 pandemic causes common fear and anxiety (Ahorsu et al., 2020). Anxiety and fear, defined as "a state of uneasiness or anxiety caused by the anticipation of a real or perceived threatening event or situation" (Spielberger, 2010), is found to be common among healthcare professionals who are directly participated in the management of patients affected during the pandemic. Moreover, due to direct contact with COVID-19 patients, health professionals are more exposed to traumatic events, such as the suffering and death of patients, which can further increase their fear and anxiety (Pappa et al., 2020).

\subsection{Perceived Organizational Support (POS) and Helping Co-Workers (HCW)}

Perceived organizational support (POS) refers to one's "beliefs about the extent to which the organization values employees' contributions and cares about their well-being" (Eisenberger et al., 1986). Studies reveal that perceived organizational support leads to positive work-related outcomes such as commitment (Panaccio and Vandenberghe, 2009; Rhoades et al., 2001), employee performance (Riggle et al., 2010). The theoretical basis for the relationship between perceived organizational support and helping co-workers can be established with social exchange theory (SET). SET has been widely preferred to explain the employees' workplace behaviors. In particular, mechanisms among outcomes and POS itself are heavily established through SET and reciprocity rule (Cropanzano and Mitchell, 2005). Thus, it is proposed that when employees feel the support of their organization, with reciprocity rule, they will intend to repay and will help coworkers. Thus, the hypothesis below was proposed:

H1: There is a positive relationship between POS and HCW.

\subsection{Perceived Organizational Support (POS) and Organizational Trust (OT)}

Organizational trust $(\mathrm{OT})$ is defined as "the willingness of a party to be vulnerable to the actions of another party based on the expectation that the other will perform a particular action important to the trustor, irrespective of the ability to monitor or control that other part" (Mayer et al., 1995) and creates a basis for the interactions among employees and their organization (Ertürk, 2014). For this study, social exchange theory may also highlight the relationship between POS and OT. When employees perceive that they are supported by their organization, with reciprocity rule, their levels of trust in the organization will increase. Studies demonstrate that organizational 
Oğuz DEMİREL \& Fuat YALMAN, 22 Cilt: 23, Sayl: 1, ss. 79-93.

support can lead to higher levels of employee trust (Chen et al., 2005; Eisenberger et al., 1990). In the light of these arguments, the hypothesis below was proposed:

$\mathrm{H} 2$ : There is a positive relationship between POS and OT.

\subsection{Organizational Trust (OT) and Helping Co-Workers (HCW)}

Organizational trust (OT) can be expected to lead to positive workplace behaviors, as it means believing in the skills and qualifications of employees at all levels of the organization (Tanner, 2007). Studies show that employees' positive attitudes and behaviors such as job satisfaction and organizational commitment improve if their trust in their organizations increases (Aryee et al., 2002; Özyılmaz et al., 2018). In addition, research demonstrates that OT increases the positive business interactions among employees such as information sharing, effective communication, and cooperation (Elewa and Aly El Banan, 2019). These results may also be expressed with the social exchange theory. It can be predicted that when health professionals trust their organization, with reciprocity rule, they will feel the need to respond and therefore will strive for their organization to be successful. As they will regard their co-workers as a part of their organization, they will help to co-workers. Therefore, the following hypothesis was established:

H3: There is a positive relationship between OT and HCW.

\subsection{The Mediating Effect of Organizational Trust (OT)}

In line with the arguments above, organizational trust can play a mediating role between perceived organizational support and helping co-workers. When employees feel that they were supported, they will trust their organization and in turn, they will show higher levels of positive workplace behaviors, including helping co-workers. Thus the following hypothesis was proposed:

H4: OT mediates the relationship between POS and HCW.

\subsection{The Moderating Effect of Fear of COVID-19 (FCOV)}

The worldwide COVID-19 outbreak has grown into a threat to both the population and health professionals (Laia et al., 2020). Because of the insufficient personal protection of healthcare workers, their exposure to a large number of infected patients for a long time (increased virus load), abnormal workload levels, and insufficient individual protective apparatus also increase the possibility of infection for healthcare workers (Wang et al., 2020). In addition, the fear of autoinoculation and the possibility of the virus spreading to their families, friends, or colleagues have raised concerns among healthcare workers (Xiang et al., 2020). This has caused them to isolate themselves without being in the family, to change their routines, to narrow their social support networks, and to restrict their social relationships (Huang et al., 2020). Based on these findings, it can be assumed that employees with low fear of COVID-19 will have high contact with their colleagues, so they will help them more. However, health professionals with higher fear of COVID-19 will have lower levels of help to their colleagues.

Based on these issues, one can conclude that the organizational trust levels of healthcare workers with low fear of COVID-19 will increase the level of assistance to their colleagues more than employees with higher fear levels, and the following hypothesis was developed:

H5: FCOV has a moderating effect on the relationship between OT and HCW; the higher the OT levels of employees with lower FCOV, the higher the level of HCW. 
MODERATED MEDIATION EFFECT OF FEAR OF COVID-19 AND ORGANIZATIONAL TRUST

ON THE RELATIONSHIP BETWEEN PERCEIVED ORGANIZATIONAL SUPPORT AND

HELPING CO-WORKERS DURING THE PANDEMIC: A STUDY ON HEALTH PROFESSIONALS

\section{METHOD}

\subsection{Sample and Procedure}

This study was conducted on health professionals working at public hospitals in Turkey. Data was collected via a web-based questionnaire due to the COVID-19 pandemic. All of the measurement items were originally developed in English, hence they were translated to Turkish via back-translation technique (Brislin, 1980).

In the first part of the survey, it is stated that participation in the study is voluntary and the data will not be shared with the third part. After the data collection process, 401 questionnaires were gathered. As there was no missing data, all of the questionnaires were included in the sample. Of the 401 participants, \%45,1 were male and \%31,9 were married.

\subsection{Measures}

Existing scales were used for all constructs. Except for the demographic questions, a 5point Likert scale was preferred for all measures (where $1=$ strongly disagree and 5=strongly agree). For reliability analysis, Cronbach's alpha coefficient was calculated for all measures and the reliability threshold was 0,70 (Nunnally, 1978).

In order to measure perceived organizational support, a twelve-item scale originally developed by Eisenberger et al. (1986) was adapted to the study. Sample items of the scale were "The hospital values my contribution to its well-being" and "The hospital really cares about my well-being". Alpha score of this scale was 0,92 .

A four-item scale developed by Nyhan and Marlowe (1992) was adapted to measure the organizational trust levels of the health professionals. Sample items were "The level of trust between employees and supervisor in this hospital is high" and "My level of confidence that this hospital will treat me fairly is high". This scale's alpha score was 0,86 .

To measure the "helping co-workers", a three-item scale used by Foulk et al. (2020) was adapted. Sample items were "I try to help someone I work with" and "I try to be available to someone I work with". The alpha reliability of this scale was 0,85 .

A seven-item scale originally developed by Ahorsu et al. (2020) was preferred to measure the levels of COVID-19 fear of the participants. Sample items of the scale were "I am most afraid of Coronavirus-19" and "It makes me uncomfortable to think about Coronavirus-19". This scale's alpha reliability score was 0,90 .

As Cronbach's alpha coefficients were all above 0,70, all of the scales were considered as reliable.

\section{RESULTS}

\subsection{Descriptive Statistics and Validity Analysis}

To test the validity of the scales, confirmatory factor analysis was performed. Results of the analysis revealed that the measurement model that contains twenty six items and four constructs (perceived organizational support, organizational trust, helping co-workers and fear of COVID-19) fit the data well $(\mathrm{CMIN} / \mathrm{df}=2,56$; $\mathrm{CFI}=0,93 ; \mathrm{GFI}=0,87$; RMSA $=0,06)$ (Schumacker and Lomax, 2010). All items were loaded on their original factors and none of the items were deleted. Composite reliability and average variance extracted values of all constructs were above 0,70 and 
Oğuz DEMİREL \& Fuat YALMAN, 22 Cilt: 23, Sayl: 1, ss. 79-93.

0,50 , respectively. Means, standard deviations, and correlations are presented for all variables in Table 1.

Table 1: Means, Standard Deviations and Correlation Coefficents

\begin{tabular}{lcccccccc}
\hline & Mean & SD & $\mathbf{1}$ & $\mathbf{2}$ & $\mathbf{3}$ & $\mathbf{4}$ & $\mathbf{5}$ & $\mathbf{6}$ \\
\hline 1) Age & 2,40 & 0,86 & - & & & & & \\
\hline 2) Gender & 1,54 & 0,49 & $-0,12^{*}$ & - & & & & \\
\hline 3) POS & 2,97 & 0,91 & 0,08 & $-0,01$ & - & & & \\
\hline 4) OT & 2,93 & 0,94 & 0,00 & $-0,10^{*}$ & $0,74^{* *}$ & - & & \\
\hline 5) HCW & 4,39 & 0,56 & 0,003 & 0,05 & $0,10^{*}$ & $0,17^{* *}$ & - & \\
\hline 6) FCOV & 2,72 & 0,95 & 0,02 & $0,26^{* *}$ & $-0,08$ & $-0,04$ & 0,03 & - \\
\hline
\end{tabular}

Note: POS = Perceived Organizational Support; OT = Organizational Trust; HCW

$=$ Helping Co-Workers; FCOV = Fear of COVID-19.

$* \mathrm{p}<0,05 . * * \mathrm{p}<0,01$.

\subsection{Findings of the Hypothesis Testing}

In order to test $\mathrm{H} 1, \mathrm{H} 2, \mathrm{H} 3$, and mediation hypothesis (H4), structural equation modeling (SEM) was preferred. Results indicate that there is a positive relationship between perceived organizational support and helping co-workers, thus H1 was supported. Findings also revealed that perceived organizational support positively affects organizational trust and there is a positive relationship between organizational trust and helping co-workers. Hence, $\mathrm{H} 2$ and $\mathrm{H} 3$ were supported. These findings are presented in Table 2.

Table 2: Results of the Hypothesis Testing

\begin{tabular}{ccccc}
\hline Hypothesis & Path & Parameter & p Value & Result \\
\hline H1 & POS $\rightarrow$ HCW & 0,11 & 0,02 & Supported \\
\hline H2 & POS $\rightarrow$ OT & 0,90 & 0,00 & Supported \\
\hline H3 & OT $\rightarrow$ HCW & 0,39 & 0,03 & Supported \\
\hline
\end{tabular}

Note: POS = Perceived Organizational Support; OT = Organizational Trust; HCW = Helping CoWorkers; $\mathrm{CMIN} / \mathrm{df}=2,45 \quad \mathrm{CFI}=0,93 \quad \mathrm{NFI}=0,90 \quad \mathrm{RMSEA}=0,06$

Another hypothesis of the study, $\mathrm{H} 4$ states that organizational trust will mediate the relationship between perceived organizational support and helping co-workers. Results of the analysis demonstrated that there is a fully mediating role of organizational trust, thus $\mathrm{H} 4$ was supported. Table 3 presents the results of these analyses. 
MODERATED MEDIATION EFFECT OF FEAR OF COVID-19 AND ORGANIZATIONAL TRUST

ON THE RELATIONSHIP BETWEEN PERCEIVED ORGANIZATIONAL SUPPORT AND

HELPING CO-WORKERS DURING THE PANDEMIC: A STUDY ON HEALTH PROFESSIONALS

Table 3: Mediation Analysis

\begin{tabular}{|c|c|c|c|c|}
\hline Hypothesis & Path & Direct Effect & Indirect Effect & Result \\
\hline $\mathrm{H} 4$ & $\mathrm{POS} \rightarrow \mathrm{OT} \rightarrow \mathrm{HCW}$ & $-0,22$ & $0,35^{*}$ & $\begin{array}{c}\text { Full } \\
\text { Mediation }\end{array}$ \\
\hline $\begin{array}{l}\text { Note: } \text { POS }=\mathrm{Pe} \\
\text { Co-Workers; } \\
\text { CMIN/df }=2,45\end{array}$ & $\begin{array}{l}\text { ceived Organizational } \\
\mathrm{CFI}=0,93 \quad \mathrm{NFI}=\end{array}$ & $\begin{array}{l}\text { pport; } \mathrm{OT}=\mathrm{Or} \\
90 \quad \text { RMSEA }\end{array}$ & $\begin{array}{l}\text { nizational Trust } \\
0,06 * \mathrm{p}<0,05\end{array}$ & $T=\mathrm{H}$ \\
\hline
\end{tabular}

In order to test the moderation hypothesis, H5, the hierarchical regression technique was preferred as suggested by Cohen and Cohen (1983). To eliminate the multicollinearity problem, the data were centered (Aiken and West, 1991). Helping co-workers (HCW) was the dependent variable and perceived organizational support (POS) was introduced to the analysis in the first step, then organizational trust (OT) in the second step, fear of COVID-19 (FCOV) which was the moderation variable in the third step and the interaction variable (OT x FCOV) in the fourth step. The results of the moderation effect analysis are given in Table 4.

Table 4: Moderation Effect of Fear of COVID-19

\begin{tabular}{|c|c|c|c|c|}
\hline \multicolumn{5}{|c|}{ Dependent Variable $=$ Helping Co-Workers } \\
\hline & Step 1 & Step 2 & Step 3 & Step 4 \\
\hline $\begin{array}{l}\text { Independent } \\
\text { Variables }\end{array}$ & $\beta(t)$ & $\beta(\mathbf{t})$ & $\beta(t)$ & $\beta(t)$ \\
\hline \multicolumn{5}{|l|}{ Step 1} \\
\hline POS & $0,10(2,11)^{*}$ & $-0,05(-, 074)$ & $-0,05(-0,67)$ & $-0,06(-0,88)$ \\
\hline \multicolumn{5}{|l|}{ Step 2} \\
\hline OT & & $0,21(2,92)^{* *}$ & $0,21(2,89) * *$ & $0,22(3,06)^{* *}$ \\
\hline \multicolumn{5}{|l|}{ Step 3} \\
\hline $\mathrm{COV}$ & & & $0,03(0,76)$ & $0,35(0,71)$ \\
\hline \multicolumn{5}{|l|}{ Step 4} \\
\hline OT x FCOV & & & & $-0,06(-1,45)$ \\
\hline $\mathrm{F}$ & $4,452 *$ & $6,530 * *$ & $4,545 * *$ & $3,946 * *$ \\
\hline $\mathrm{R}^{2}$ & 0,011 & 0,032 & 0,033 & 0,038 \\
\hline $\begin{array}{l}\text { Note: POS = } \\
\text { Co-Workers; } \\
* \mathrm{p}<0,05 . * * \mathrm{p}\end{array}$ & $\begin{array}{l}\text { Organizationa } \\
\text { ear of COVID }\end{array}$ & ipport; OT = C & anizational Tru & $\mathrm{HCW}=$ Helpin \\
\hline
\end{tabular}

Fear of COVID-19, which was the moderation variable, did not have a significant effect on helping co-workers $(\beta=0.03 ; \mathrm{t}=0.76 ; \mathrm{p}>0.05)$. In addition, the interaction effect (OT $\mathrm{x}$ FCOV) of organizational trust and fear of COVID-19 on helping co-workers was also not statistically significant $(\beta=-0.06 ; \mathrm{t}=-1.45 ; \mathrm{p}>0.05)$. Findings revealed that fear of COVID-19 did not have a moderation effect on the association between organizational trust and helping co-workers. Therefore, H5 was not supported. 
Oğuz DEMİREL \& Fuat YALMAN, 22 Cilt: 23, Sayl: 1, ss. 79-93.

\section{CONCLUSION}

In this study, the influence of perceived organizational support on helping co-workers and the mediation role of organizational trust was investigated. Second, whether fear of the COVID-19 disease, which emerged in China in December 2019 and became a pandemic in 2020, could play a moderating role in the relationship between organizational trust and helping co-workers was examined. The unique value of the study is that no other research has been found that addresses the relationship between perceived organizational support, organizational trust, and helping coworkers in the context of fear of COVID-19.

The first hypothesis, H1, which proposes that perceived organizational support has a positive effect on HCW was supported. As consistent with this result, previous research show that perceived organizational support creates positive workplace behaviors (Eisenberger et al., 1997; Özdevecioğlu, 2004). H2 was supported, indicating that perceived organizational support has a positive effect on organizational trust. This result is similar to the previous studies, pointing out that when employees' perceptions about organizational support increase, the trust in their organization also increases (Chen et al., 2005; Shukla and Rai, 2015). H3 of this study, which proposes that organizational trust has a positive effect on HCW was also supported. This result is also in parallel with previous studies, demonstrating that higher levels of organizational trust increase positive workplace behaviors (Altuntas and Baykal, 2010; Demircan and Ceylan, 2003).

The mediation hypothesis, H4 was supported. Perceived organizational support has a positive effect on helping co-workers through organizational trust. If health professionals perceive their organization's support, their trust level increases, and in turn, their helping to co-workers also increases. This result supports the social exchange theory. And this finding may be considered as important and unique as the authors could not reach a similar result in the literature.

The study revealed that health professionals' fear of COVID-19 did not have any significant moderating role on the relationship between organizational trust and helping co-workers, thus H5 was not supported. This finding is consistent with past research as well. In a study conducted on nurses, the majority of nurses $(96.8 \%)$ during the COVID-19 outbreak stated that they were willing to work at the forefront despite any conditions, for reasons such as responsibility and duty as a nurse, previous experiences gained during the SARS epidemic, patriotism, dedication, helping others and hospital duty (Hu et al., 2020). In another study, it was emphasized that the nursing desire or purpose of providing voluntary and active care to patients during newly emerging infectious diseases alleviates burnout, anxiety, depression and fear of nurses (Oh et al., 2017).

According to the findings of the study, hospital managers may be advised to make the health professionals feel supported by the organization. In this direction, it may be suggested that the complaints of the employees should be taken into consideration, the opinions of the health professionals should be evaluated while making decisions about them and these opinions should be reflected in the decisions as much as possible.

This study has some limitations. First, the research data were collected at a time and from only one source. Therefore, the problem of common method variance is likely to arise (Podsakoff et al., 2003). However, results of the confirmatory factor analysis demonstrated that the measurement items were not gathered under a single factor, pointing out that common method variance is not a major problem for this study. It is recommended to collect data from different sources in future studies. For example, data on helping co-workers can be obtained from colleagues. In addition, collecting data at once and in the same time period can cause problems in 
MODERATED MEDIATION EFFECT OF FEAR OF COVID-19 AND ORGANIZATIONAL TRUST ON THE RELATIONSHIP BETWEEN PERCEIVED ORGANIZATIONAL SUPPORT AND HELPING CO-WORKERS DURING THE PANDEMIC: A STUDY ON HEALTH PROFESSIONALS

establishing a causality relationship between variables. Therefore, it is recommended to conduct longitudinal studies. Second, this study was carried out in public hospitals in Turkey. In order to generalize the findings of the behaviors of healthcare professionals, future studies may investigate the relationships in private hospitals and other healthcare organizations. Also, it is recommended to conduct research on different cultural contexts. 
Oğuz DEMİREL \& Fuat YALMAN, 22 Cilt: 23, Sayl: 1, ss. 79-93.

\section{REFERENCES}

Ahorsu, D. K., Lin, C.Y., Imani, V., Saffari, M., Griffiths, M. D., \& Pakpour, A. H. (2020). The Fear of COVID-19 Scale: Development and Initial Validation. International Journal of Mental Health and Addiction. https://doi.org/10.1007/s11469-020-00270-8

Aiken, L. S., \& West, S. G. (1991). Multiple Regression Analysis: Testing and Interpreting Interactions. Sage.

Altuntas, S., \& Baykal, U. (2010), Relationship Between Nurses' Organizational Trust Levels and Their Organizational Citizenship Behaviors. Journal of Nursing Scholarhip, 42(2), 186194.

Aryee, S., Budhwar, P. S., \& Chen, Z. X. (2002). Trust as a Mediator of the Relationship Between Organizational Justice and Work Outcomes: Test of a Social Exchange Model. Journal of Organizational Behavior, 23(1), 267-285.

Baker, M.G., Peckham T.K., \& Seixas N. S. (2020). Estimating the Burden of United States Workers Exposed to Infection or Disease: A Key Factor in Containing the Risk Of COVID19 Infection. PLOS One, 15(4). https://doi.org/10.1101/2020.03.02.20030288

Brislin, R. W. (1980). Translation and Content Analysis of Oral and Written Materials, Triandis, H. C., \& Berry, J. W. (Eds.), Handbook of Cross-Cultural Psychology, 2. Allyn and Bacon.

Chen, Z. X., Aryee, S., \& Lee, C. (2005). Test of a Mediation Model of Perceived Organizational Support. Journal of Vocational Behavior, 66(3), 457-470.

Cheung, M. F. Y. (2013). The Mediating Role of Perceived Organizational Support in the Effects of Interpersonal and Informational Justice on Organizational Citizenship Behaviors. Leadership \& Organization Development Journal, 34(6), 551-572.

Choi, B. K., \& Moon, H. K. (2016). Prosocial Motive and Helping Behavior: Examining Helping Efficacy and Instrumentality. Journal of Managerial Psychology, 31(2). 359-374.

Cohen, J., \& Cohen, P. (1983). Applied Multiple Regression/Correlation Analyses for the Behavioral Sciences (2nd Edition). Lawrence Elbaum.

Cropanzano, R., \& Mitchell, M. S. (2005). Social Exchange Theory: An Interdisciplinary Review. Journal of Management, 31(6), 874-900.

De Clercq, D., Rahman, Z., \& Ul Haq, I. (2019). Explaining Helping Behavior in the Workplace: The Interactive Effect of Family-to-Work Conflict and Islamic Work Ethic. Journal of Business Ethics, 155, 1167-1177.

Demircan, N., \& Ceylan, A. (2003). Örgütsel Güven Kavramı, Nedenleri ve Sonuçları. Journal of Management and Economy, 10(2), 139-150.

Eiserberger, R., Huntington, R., Hutchison, S., \& Sowa, D. (1986). Perceived Organizational Support. Journal of Applied Psychology, 71(3), 500-507.

Eisenberger, R., Fosalo, P., \& Davis-LaMastro, V. (1990). Perceived Organizational Support and Employee Diligence, Commitment, and Innovation. Journal of Applied Psychology, 75, 51 59. 
MODERATED MEDIATION EFFECT OF FEAR OF COVID-19 AND ORGANIZATIONAL TRUST

ON THE RELATIONSHIP BETWEEN PERCEIVED ORGANIZATIONAL SUPPORT AND

HELPING CO-WORKERS DURING THE PANDEMIC: A STUDY ON HEALTH PROFESSIONALS

Eisenberger, R., Cummings, J., Armeli, S., \& Lynch, P. (1997). Perceived Organizational Support, Discretionary Treatment and Job Satisfaction. Journal of Applied Psychology, 82(5), 812820.

Elewa, A. H., \& Aly El Banan, S. H. (2019). Organizational Culture, Organizational Trust and Workplace Bullying Among Staff Nurses at Public and Private Hospitals. International Journal of Nursing Didactics, 9(4), 10-20.

Erdem, D., Atçı, H., Akan, B., Albayrak, D., Gökçınar, D., \& Göğüş, N. (2010). The Effect of Intensive Care Work Periods of Anesthesiology and Reanimation Clinic Assistants on Burnout, Occupational Performance, Work-Related Tension and State-Trait Anxiety Levels. Sisli Etfal Hospital Medical Bulletin, 44, (3), 93-99.

Ertürk, A. (2014). Influences of HR Practices, Social Exchange, and Trust on Turnover Intentions of Public IT Professionals. Public Personnel Management, 43(1), 140-175.

Foulk, T. A., De Pater, I. E., Schaerer, M., Du Plessis, C., Lee, R., \& Erez, A. (2020). It's Lonely at the Bottom (Too): The Effects of Experienced Powerlessness on Social Closeness and Disengagement. Personnel Psychology, 73, 363-394.

Hu, D., Kong, Y., Lic, W., Hand, Q., Zhange, X., Zhuf, L. X., Wanf, S. W., Liuc, Z., Shenc, Q., Yangc, J., He, H. G., \& Zhu, J. (2020). Frontlinenurses' Burnout, Anxiety, Depression, and Fear Statuses and Their Associated Factors During the COVID-19 Outbreak in Wuhan, China: A Large-Scale Cross-Sectional Study. EClinicalMedicine, 24, 100424.

Huang, J. Z., Han, M. F., Luo, T. D., Ren, A. K., \& Zhou, X. P. (2020). Mental Health Survey of 230 Medical Staff in a Tertiary Infectious Disease Hospital for COVID-19. Chinese Journal of Industrial Hygiene and Occupational Diseases, 38(3), 192-195.

Laia, C. C., Shih, T. P., Ko, W. C., Tang, H. J., \& Hsueh, P. R. (2020). Severe Acute Respiratory Syndrome Coronavirus 2 (SARS-Cov-2) and Coronavirus Disease-2019 (COVID-19): The Epidemic and the Challenges. International Journal of Antimicrobial Agents, 55(3), 105924.

Massholder, K., Richardson, H. A., \& Settoon, R. P. (2011). Human Resource Systems and Helping in Organizations: A Relational Perspective. Academy of Management Review, 36(1), 3352.

Mayer, R. C., Davis, J. H., \& Schoorman, F. D. (1995). An Integrative Model of Organizational Trust. Academy of Management Review, 20(3), 709-734.

Moorman, R. H., Blakely, G. L., \& Niehoff, B. P. (1998). Does Perceived Organizational Support Mediate the Relationship Between Procedural Justice and Organizational Citizenship Behavior?. Academy of Management Journal, 41(3), 351-357.

Lim, J. Y., \& Moon, K. K. (2020). Transformational Leadership and Employees' Helping Behavior in Public Organizations: Does Organizational Structure Matter?. Public Personnel Management, https://doi.org/10.1177/0091026020977565.

Nunnally, J. (1978). Psychometric Methods (2nd Edition). McGraw-Hill.

Nyhan, R. C., \& Marlowe, H. A. (1997). Development and Psychometric Properties of the Organizational Trust Inventory. Evaluation Review, 21(5), 614-635. 
Oğuz DEMİREL \& Fuat YALMAN, 22 Cilt: 23, Sayl: 1, ss. 79-93.

Oh, N., Hong, N., Ryu, D. H., Bae, S. G., Kam, S., \& Kim, K. Y. (2017). Exploring Nursing Intention, Stress, and Professionalism in Response to Infectious Disease Emergencies: The Experience of Local Public Hospital Nurses During the 2015 MERS Outbreak in South Korea. Asian Nursing Research, 11(3), 230-236.

Özdevecioğlu, M. (2004), Algılanan Örgütsel Desteğin İşten Ayrılma Niyeti Üzerindeki Etkileri. Amme İdaresi Dergisi, 37(4), 97-115.

Özyılmaz, A., Erdoğan, B., \& Karaeminoğulları, A. (2018). Trust in Organization as a Moderator of the Relationship Between Self-Efficacy and Workplace Outcomes: A Social Cognitive Theory-Based Examination. Journal of Occupational and Organizational Psychology, 91, 181-204.

Panaccio, A., \& Vandenberghe, C. (2009). Perceived Organizational Support, Organizational Commitment and Psychological Well-Being: A Longitudinal Study. Journal of Vocational Behavior, 75(2), 224-236.

Pappa, S., Ntella, V., Giannakas, T., Giannakoulis, V. G., Papoutsi, E., \& Katsaounou, P. (2020). Prevalence of Depression, Anxiety, and Insomnia Among Healthcare Workers During the COVID-19 Pandemic: A Systematic Review and Meta-Analysis. Brain, Behavior and Immunity, 88, 901-907.

Podsakoff, P. M., MacKenzie, S. B., Paine, J. B., \& Bachrach, D. G. (2000), Organizational Citizenship Behaviors: A Critical Review of the Theoretical and Empirical Literature and Suggestions for Future Research. Journal of Management, 26, 513-563.

Podsakoff, P. M., Mackenzie, S. B., Lee, J. Y., \& Podsakoff, N. P. (2003). Common Method Biases in Behavioral Research: A Critical Review of the Literature and Recommended Remedies. Journal of Applied Psychology, 88(5), 879-903.

Psychiatric Association of Turkey (2020, 24 November). Covid-19 Tedavisinde Önleyici, Когиуиси ve Tedavi Edici Psikiyatrik Hizmetler. https://www.psikiyatri.org.tr/TPDData/Uploads/files/COVID19_Pandemi_PsikiyatrikTed avilerTPDRTACB-05052020.pdf

Rajkumar, R. P. (2020). COVID-19 and Mental Health: A Review of the Existing Literature. Asian Journal of Psychiatry, 52, 102066.

Rhoades, L., Eisenberger, R., \& Armeli, S. (2001). Affective Commitment to the Organization: The Contribution of Perceived Organizational Support. Journal of Applied Psychology, 86(5), 825-836.

Riggle, R. J., Edmondson, D. R., \& Hansen, J. D. (2010). A Meta-Analysis of the Relationship Between Perceived Organizational Support and Job Outcomes: 20 Years of Research. Journal of Business Research, 62(10), 1027-1030.

Schumacker, R. E., \& Lomax, R. G. (2010). A Beginner's Guide to Structrual Equation Modeling (3rd Edition). Routledge.

Shigemura, J., Ursano, R. J., Morganstein, J. C., Kurosawa, M., \& Benedek, D. M. (2020). "Public responses to the novel 2019 coronavirus $(2019-n C o V)$ in Japan: Mental health consequences and target populations". Psychiatry and Clinical Neurosciences, 74(4), 281282. 
MODERATED MEDIATION EFFECT OF FEAR OF COVID-19 AND ORGANIZATIONAL TRUST

ON THE RELATIONSHIP BETWEEN PERCEIVED ORGANIZATIONAL SUPPORT AND

HELPING CO-WORKERS DURING THE PANDEMIC: A STUDY ON HEALTH PROFESSIONALS

Shukla, A., \& Rai, H. (2015). Linking Perceived Organizational Support to Organizational Trust and Commitment: Moderating Role of Psychological Capital. Global Business Review, 16(6), 981-996.

Spielberger, C. D. (2010). State-Trait Anxiety Inventory. The Corsini Encyclopedia of Psychology. https://doi.org/10.1002/9780470479216.corpsy0943

Tanner, B. M. (2007). Analysis of the Relationships Among Job Satisfaction, Organizational Trust, and Organizational Commitment in an Acute Care Hospital [Ph.D Thesis]. Faculty of Saybrook Graduate School and Research Center.

Torales, J., O’Higgins, M., Castaldelli-Maia, J. M., \& Ventriglio, A. (2020). The Outbreak of COVID-19 Coronavirus and Its Impact on Global Mental Health. International Journal of Social Psychiatry, 66(4), 317-320.

Wang, J., Zhou, M., \& Liu, F. (2020). Reasons for Health Care Workers Becoming Infected with Novel Coronavirus Disease 2019 (COVID-19) in China. Journal of Hospital Infection, 105(1), 100-101.

World Health Organization (2020, 20 November). Coronavirus Disease (COVID-19) Advice for the public. https://www.cdc.gov/coronavirus/2019-ncov/need-extra-precautions/people-athigher-risk.html

World Health Organization (2020, 15 November). Coronavirus. https://www.who.int/healthtopics/coronavirus\#tab=tab_1

Xiang, Y. T., Yang, Y., Li, W., Zhang, L., Zhang, Q., Cheung, T., \& Ng, C. H. (2020). Timely Mental Health Care for the 2019 Novel Coronavirus Outbreak is Urgently Needed. Lancet Psychiatry, 7(3), 228-229.

Zhang, M. Zhou, M., Tang, F., Wang, Y., Nie, W., Zhang, L., \& Gou, Y. (2020). Knowledge, Attitude, and Practice Regarding COVID-19 Among Healthcare Workers in Henan, China. Journal of Hospital Infection, 105(2), 183-187.

Zhu, Y., \& Akhtar, S. (2014). How Transformational Leadership Influences Follower Helping Behavior: The Role of Trust and Prosocial Motivation. Journal of Organizational Behavior, 35, 372-395. 
Oğuz DEMíREL \& Fuat YALMAN, 22 Cilt: 23, Sayl: 1, ss. 79-93.

\section{EXTENDED ABSTRACT}

In order the reach higher levels of performance, organizations must create a climate that encourages employees to show positive workplace behaviors. One of these behaviors is helping co-workers, which includes extra efforts of employees for helping their co-workers while they perform their duties. Studies revealed that perceived organizational support and organizational trust are prominent factors that stimulate positive workplace behaviors.

Due to the spread of the virus to Europe and the U.S. in a short time, the World Health Organization has declared COVID-19 as a pandemic (global epidemic) as of March 11, 2020. As the pandemic brings up many additional medical or social behavior changes, it has been emphasized that the obligation to comply with the rules requires a sustainable adaptation skill. Health professionals are the main actors of battle with this pandemic. Thus, it can be predicted that fear of COVID-19 may create medical and social behavior changes.

Thus, the purpose of this study is to investigate the effect of perceived organizational support on helping behaviors of health professionals and whether fear of COVID-19 has a moderation effect on this relationship.

The study was used quantitative research methods. In order to obtain data, the survey method was preferred and an online questionnaire form on Google Forms was administrated. After the data collection process, 401 questionnaires were returned. As there was no missing data, 401 survey forms constituted the sample. In the first step of the analysis, a confirmatory factor analysis was performed and findings revealed that the measurement model (which contained perceived organizational support, organizational trust, helping co-workers and fear of COVID-19) fit the data well. Then, hypothesis testing procedures were performed. In order to test H1, H2, H3, and H4 structural equation modeling were preferred. For the moderation hypothesis, H5, hierarchical regression analysis was used.

Findings of the hypothesis testing demonstrated that perceived organizational support has a positive effect on helping behavior. If health professionals feel that their organization's support, they help their co-workers. Second finding revealed that perceived organizational support has a positive effect on organizational trust, meaning that higher levels of organizational support create higher levels of employee trust in the organization. Third, organizational trust has a positive effect on helping co-workers. When health professionals trust in their organizations, they regard their coworkers as a part of the organization, and thus, they show helping behaviors. Fourth, organizational trust mediates the relationship between perceived organizational support and helping behaviors. If the organizational support perceptions of health Professionals increase, their trust in the organization increases and this leads to a rise in helping behaviors. Finally, fear of COVID-19 has no moderation effect on this relationship.

According to the findings of the study, hospital managers may be advised to make the health professionals feel supported by the organization. In this direction, it may be suggested that the complaints of the employees should be taken into consideration, the opinions of the health professionals should be evaluated while making decisions regarding them and these opinions should be reflected in the decisions as much as possible. This will lead to higher levels of trust and helping behaviors. This study was carried out in public hospitals in Turkey. In order to generalize the findings of the behaviors of healthcare professionals, future studies may investigate the relationships in private hospitals and other healthcare organizations. Also, it is recommended to conduct research on different cultural contexts. 